--Raf.J. Sci.,Vol.27, No.4 /Special Issue for the Third Scientific Conference of Biology, pp.90-102, 2018--

\title{
Synthesis and Evaluation the Activity of 1,3,4-Thiadiazole Derivatives as Antibacterial Agent Against Uncommon Bacteria Causes of Urinary Tract Infections
}

\author{
Shaymaa N. Daham \\ Department of Biology/College of Education/ University of Samarra \\ Marwa H. Abdullwahab \\ Department of Biology/ College of Science/ University of Tikrit \\ Asmaa E. Mahmood \\ Department of Pathological Analyzes/College of Applied Sciences/ University of Samarra \\ Evon Akram \\ Department of Chemistry/ College of Science/ University of Al-Nahrain
}

(Received 30/9/2018; Accepted 1/11/2018)

\section{ABSTRACT}

Schiff base compound 5-(benzylideneamino)-1,3,4-thiadiazole-2-thiol was prepared from condensation reaction of 2-amino-5-mercapto-1,3,4-thiadiazole with benzaldehyde. New Schiff bases react with copper (II), Ferric (III), Cobalt (II) and Zinc (II) to form four complexes. The Schiff base complexes were identification by using FTIR and UV-VIS. The antibacterial activity of complexes (Copper (II) $\mathrm{LM}_{1}$, Ferric (III) $\mathrm{LM}_{2}$, Cobalt (II) $\mathrm{LM}_{3}$ and Zinc (II) $\mathrm{LM}_{4}$ complexes) were studied against Kocuria kristinae, Alloiococcus otiti and Aerococcus urinae as a model of Gram positive, Pseudomonas stutzeri, Ochrobactrum anthropic and Pantoea agglomerans as a model of Gram negative to determine the activity of synthesized complexes. Identification of these uncommon bacteria that isolated from urinary tract infection confirmed by using VITEK2 compact system. Several antibiotics have been chosen to investigate the ability of these isolates to resist the conventional antibiotic. The results showed higher activity of the new compounds relative to the chosen antibiotics.

Keywords: Synthesis, 1,3,4-thiadiazole, uncommon bacteria, antibiotic, antibacterial agent.

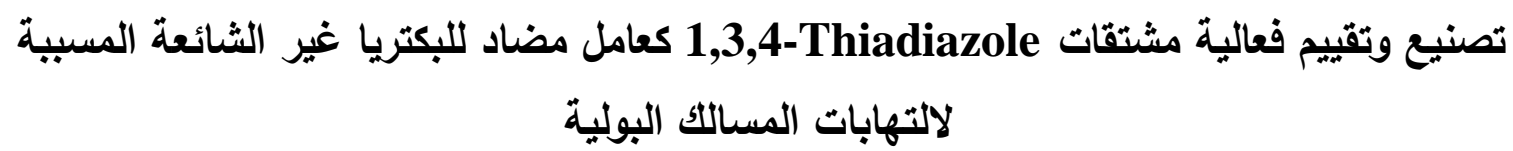

\section{الملخص}

5-benzylideneamino)-1,3,4-(b) تمضير مركب قاعة شيف 5-بينزيلادين امينو -1,3,4 ثاديازول-2-ثايول 2-amino-5-mercapto-1,3,4- من تفاعل تكتثف 2- امينو-5 ميركابتو-1,3,4 ثناديازول (thiadiazole-2-thiol thiadiazole الحديد (III)، الكوبلت (III) و الزنك (II). شخصت معقدات قاعدة شيف باستعمال جهاز محول الاشعة تحت الحمراء Fourier) .V-visible spectroscopy (UV-VIS) و جهاز المطياف الضوئي Transform-Infrared Spectroscopy (FTIR) ولتحديد فعالية المعقدات المصنعة نم دراسة الفعالية البيولوجية للمعقدات (النحاس LM (II)، الحديد LM (III)، الكوبلت

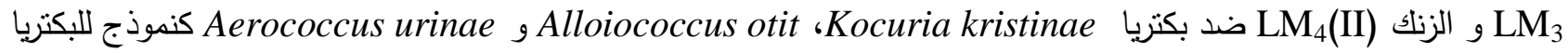
الموجبة لصبغة غرام وبكتريا Ochrobactrum anthropic Pseudomonas stutzeri و Pantoea agglomerans كنموذج للبكتريا السالبة لصبغة غرام. نم تأكيد نشخيص البكتريا الغير شائعة والمعزولة من التهابات المسالك البولية باستعمال 


$$
\begin{aligned}
& \text { جهاز الفايتك 2. اختيرت العديد من المضادات الحيوية للتحري عن قابلية تلك العزلات على مقاومة المضادات الحيوية التقليدية. } \\
& \text { وقد اظهرت النتائج فعالية عالية للمركبات الجديدة مقارنة بالمضادات الحيوية المنتخبة. } \\
& \text { الكلمات الدالة: تصنيع، 1,3,4-thiadiazole، بكتريا غير شائعة، مضادات حيوية، عامل مضاد بكتيري. }
\end{aligned}
$$

\section{INTRODUCTION}

Urinary tract infection (UTI) is one of the most common and frequent medical infections and affects all ages (Hooton, 2000). Accurate diagnosis and successful treatment of infection in most cases has helped minimize secondary outcomes. UTI may occur in up to $50 \%$ of all women in their lifetimes and frequently require medication (Zafenello et al., 2010). There are some bacterial species that are uncommon or infrequently exist in clinical sample such as Kocuria kristinae that was first described in 1974 (Kloos et al., 1974). There are some reports of K. kristinae associated infections in patients, especially those with malignancies or other immunosuppressed states (Cheung et al., 2011). Alloiococcus otitis has been quite difficult to isolate using conventional culture methods. On the other hand, studies have indicated that A. otitis has the ability to stimulate the immune system and to induce a local immune response in the middle ear cavity (Leskinen et al., 2002) Aerococcus urinae is a newcomer in clinical and microbiological practice, first reported in 1989 and designated in 1992 (Aguirre and Collinis 1992). A. urinae has also been isolated from blood from patients suffering from urogenic bacterimea or septicemia with or without endocarditis (Skov et al., 1995). Pseudomonas stutzeri that causes local and systematic infections (Grimaldi et al., 2009) and Ochrobactrum anthropi that become increasingly recognized as a potentially problematic, opportunistic, and nosocomial pathogen (Chain et al., 2011). Clinical strains of $O$. anthropi are multiresistant to common antibiotics, in particular they are usually resistant to all $\beta$-lactams except imipenem. (Nadjar et al., 2001). Pantoea agglomerans formerly known as Enterobacter agglomerans, is most commonly isolated in hospitals (De Baere et al., 2004).

Heterocyclic compounds possessing 1,3,4-thiadiazol ring system show antifungal, bacteriostatic and containing compounds represent an important class of heterocyclic nitrogen compounds and their derivatives are characterized with a broad spectrum of biological activity in both agrochemical (Ana et al., 2010) as well as anthelmintic effects. Compounds containing the above ring also exhibit anti-inflammatory, antimicrobial (Laura et al., 2010) properties and the depression effect on the central nervous system. In the field of archaeological conservation, aminomercapto-1, 3, 4-thiadiazole is the most widely used corrosion inhibitor in the treatment of bronze artifacts. Schiff bases are characterized by the $-\mathrm{N}=\mathrm{CH}$-(imine) group which is important in elucidating the mechanism of transformation in biological systems. Due to great flexibility and diverse structural aspects a wide range of Schiff bases have been synthesized and their complexation behavior studied .Furthermore Schiff bases are reported to show a variety of interesting biological activities including antibacterial, antifungal, anti-mouse hepatitis virus (MHV), anticancer and herbicidal activities. It is also known that the presence of an azo moiety in different types of Schiff bases can lead them to exhibit pesticidal activities (Yasser et al., 2010). Both Schiff bases and azo compounds are important structures in the medicinal and pharmaceutical fields and it has been suggested that the azomethine linkage might be responsible for biological activities displayed by Schiff bases (Ispir et al., 2005). Furthermore, Schiff bases have five membered heterocyclic compounds show various types of biological activity among them 2,5disubstituted 1,3,4-thiadiazoles are associated with diverse biological activities probably, due to $\mathrm{N}=\mathrm{C}-\mathrm{S}$ - grouping (21). Thiadiazoles are five membered aromatic ring compounds with three hetero atoms .One sulfur atom and two nitrogen atoms (Georgeta et al., 2010). There are four isomeric types of thiadiazoles (Vasiliy et al., 2017): (a) 1,2,3-thiadiazole; (b) 1,3,4-thiadiazole; (c) 1,2,4thiadiazole; and (d) 1,2,5-thiadiazole as shown scheme (1): 


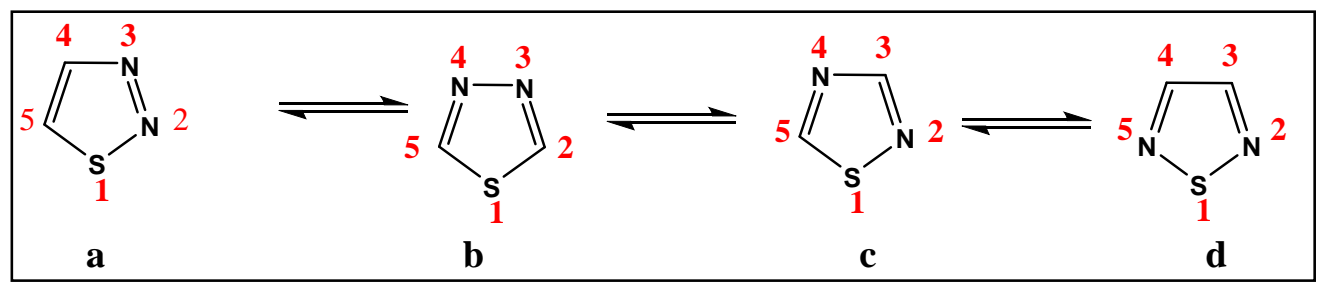

\section{Scheme 1: Structures of Thiadiazoles isomer}

\section{MATERIAL AND METHODS}

Preparation of 2-amino-5-mercapto-1,3,4-thiadiazole (Salih, 2005).

A mixture of $(13.5 \mathrm{~g}, 0.1$ mole $)$ of thiosemicarbazide and $(0.56 \mathrm{~g}, 0.1 \mathrm{~mole})$ of $\mathrm{KOH}$ in $70 \mathrm{ml}$ absolute ethanol, to this solution $(18.3 \mathrm{~g}, 0.24 \mathrm{~mole})$ of carbon disulfide was added drop wise. The resulting mixture was heated under reflux for 6 hours, and then was allowed to cool down to room temperature. Carefully acidified with concentration $\mathrm{HCl}$ to give pale yellow precipitate. The crude product was filtered and washed with cold water, re-crystallized from ethanol to give the desired product as yellow needles, melting point was reported $(180-185)^{\circ} \mathrm{C}$, shown in scheme (2).

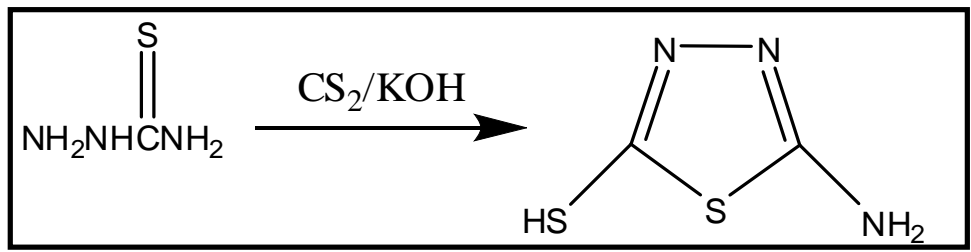

Scheme 2: preparation of 2-amino-5-mercapto-1,3,4-thiadiazole

Preparation of 5-(benzylideneamino)-1,3,4-thiadiazole-2-thiol (Abdul-Jabar et al., 2014).

A mixture of 2-amino-5-mercapto-1,3,4-thiadiazole $(1.33 \mathrm{~g}, 0.01 \mathrm{~mole})$ and benzaldehyde (0.01 mole) was dissolved in $20 \mathrm{ml}$ absolute ethanol and 1-2 drops of glacial acetic acid were refluxed for (5-6) hrs. After cooling to room temperature the precipitate was filtered and dried. The product was re-crystallized from ethanol yield white crystal precipitate, melting point was reported $(140-145)^{\circ} \mathrm{C}$, shown in scheme (3).

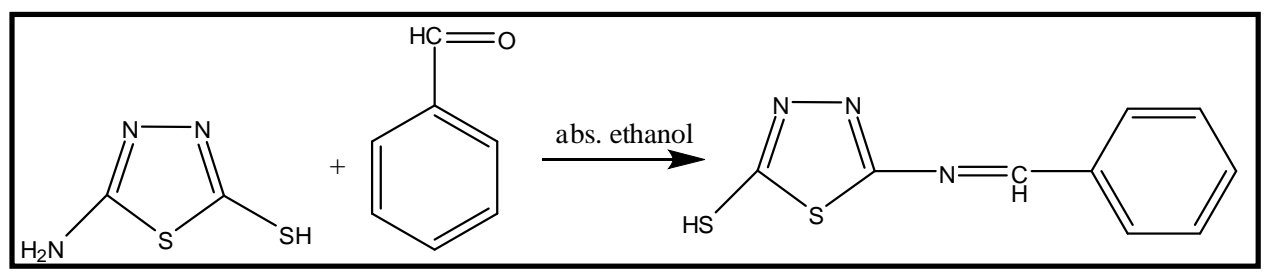

Scheme 3: Preparation of 5-(benzylideneamino)-1,3,4-thiadiazole-2-thiol.

\section{Preparation of 5-(benzylideneamino)-1,3,4-thiadiazole-2-thiol complexes}

All the complexes were prepared according to (Kadhim et al., 2014; Singh et al., 2015).

\section{Copper (II) Complexes ( $\left.\mathrm{LM}_{1}\right)$}

Add $(0.219 \mathrm{~g}, 0.001 \mathrm{~mole})$ of 5-(benzylideneamino)-1,3,4 thiadiazole-2-thiol to alcoholic solution $\left[\mathrm{CuCl}_{2} .2 \mathrm{H}_{2} \mathrm{O}(0.341 \mathrm{~g}, 0.002\right.$ mole $)$ in $10 \mathrm{ml}$ of absolute ethanol], then the mixture was refluxed for $3 \mathrm{hrs}$. The gray precipitate was product and then filtered and washed with absolute ethanol and dried it in room temperature. 


\section{Ferric (III) Complexes ( $\left.\mathrm{LM}_{2}\right)$}

Add $(0.219 \mathrm{~g}, 0.001 \mathrm{~mole})$ of 5-(benzylideneamino)-1,3,4-thiadiazole-2-thiol to alcoholic solution $\left[\mathrm{FeCl}_{3} .6 \mathrm{H}_{2} \mathrm{O}(0.273 \mathrm{~g}, 0.001 \mathrm{~mole})\right.$ in $10 \mathrm{ml}$ of absolute ethanol], then the mixture was refluxed for $3 \mathrm{hrs}$. The gelatinous olive precipitate was product and then filtered and washed with absolute ethanol and dried it in vacuum.

\section{Cobalt (II) Complexes ( $\mathrm{LM}_{3}$ )}

Add $(0.219 \mathrm{~g}, 0.001 \mathrm{~mole})$ of 5-(benzylideneamino)-1,3,4-thiadiazole-2-thiol to alcoholic solution [ $\mathrm{CoCl}_{2} \cdot 6 \mathrm{H}_{2} \mathrm{O}(0.23 \mathrm{~g}, 0.002 \mathrm{~mole})$ in $10 \mathrm{ml}$ of absolute ethanol], the mixture was refluxed for 3 hrs. The brown precipitate was product and then filtered and washed it with absolute ethanol and dried it in room temperature.

\section{Zinc (II) Complexes $\left(\mathrm{LM}_{4}\right)$}

Add (0.219 g, 0.001 mole) of 5-(benzylideneamino)-1,3,4-thiadiazole-2-thiol to alcoholic solution $\left[\mathrm{ZnCl}_{2} .2 \mathrm{H}_{2} \mathrm{O}(0.237 \mathrm{~g}, 0.002 \mathrm{~mole})\right.$ in $10 \mathrm{ml}$ of absolute ethanol], the mixture was refluxed for 3 hrs. The yellow gelatinous precipitate was product and then filtered and washed it with absolute ethanol and dried it in room temperature.

\section{Instrument Chemical Analyzes \\ Infrared Spectra}

The Infrared Spectra of Schiff bases compounds and complexes were recorded by using FTIR spectroscopy (Bruker, ALPHA), this analysis was carried out in the Chemistry Department of AlNahrain University.

\section{UV -VIS Spectra}

The UV -VIS spectra of Schiff bases compounds and complexes were recorded by using Shimadzu UV-1650PC -Visible recoding spectro photometer, this analysis was carried out in the Chemistry Department of Al-Nahrain University.

\section{Collection of Uncommon Pathogenic Bacterial Isolates}

All uncommon pathogenic bacteria were obtained from the (Laboratory of the Department of Biology/ College of Education for Pure Sciences/ University of Samarra). The identification of bacteria was performed using VITEK2 compact system. The pathogenic bacterial isolates were cultivated on selective media in the laboratory and stained by Gram stain and some biochemical tests were done as confirmation diagnostic tests (Mahon et al., 2015). All the collected isolates were isolated from urinary tract infections.

\section{Antibiotic Susceptibility Test}

The disc diffusion method was used to determine antibiotic sensitivity of the isolates using the method described by Kirby-Bauer cited by (Vandepitte et al., 2003). The results were compared with the standard diameter of inhibition zones for each antibiotic according to (CLSI, 2007). The twenty four antibiotic discs used in this research were Meropenem, Dorepenm, Azteronam, Penciilin G, Pipracillin, Ampicillin, Amoxiclave, Cefotacxime, Ceftriaxon, Cefazolin, Cephalothin, Cefadroxil, Cefexime, Cefepem, Ceftazidime, Ciprofloxacin, Levofloxacin, Amikacin, Netilmicin, Tobramycin, Nitrofurantion, Doxicycline, Tetracycline and Trimethoprime. (Bioanalyse/ India).

\section{Antibacterial Activity of Complexes}

The antibacterial activities of synthesized complexes were evaluated against some uncommon (Kocuria kristinae, Alloiococcus otiti and Aerococcus urinae as gram positive) and (Pseudomonas stutzeri, Ochrobactrum anthropic and Pantoea agglomerans as model of gram negative) using well 
diffusion method. $0.2 \mathrm{ml}$ of fresh cultures of each organism was inoculated into $5 \mathrm{ml}$ of sterile nutrient broth (Himedia/ India) and incubated for $3-5 \mathrm{~h}$ to standardize the culture to McFarland standard $\left(1.5 \times 10^{8} \mathrm{CFU} / \mathrm{ml}\right) .0 .1 \mathrm{ml}$ of each culture of microorganism was spreading on Mueller Hinton Agar (Himedia/ India). Wells were made using gel puncture (6mm) according to (Egorove, 1985), then $0.1 \mathrm{~mL}$ of different dilutions $(0.1,0.03 .0 .05 \mathrm{M})$ in case of Copper (II) complexes : (Dissolved Copper (II) complexes $(0.1 \mathrm{~g}, 0.2 \mathrm{~g}$ and $0.3 \mathrm{~g}$ ) in $2 \mathrm{ml}$ Dimethyl sulfoxide (DMSO), while the dilutions $(0.1,0.2,0,3 \mathrm{M})$ in case of Ferric (III) complexes: (Dissolved $(0.1 \mathrm{~g}, 0.2 \mathrm{~g}$ and $0.3 \mathrm{~g}$ ) of Ferric (III) complexes in $2 \mathrm{ml}$ abs. ethanol), Cobalt (II) complexes : $(0.1 \mathrm{~g}, 0.3 \mathrm{~g}$ and $0.5 \mathrm{~g}$ of Cobalt (II) complexes and dissolved in 2ml DMSO), and Zinc (II) complexes: (Add 2ml ethanol to each of $(0.1 \mathrm{~g}, 0.2 \mathrm{~g}$ and $0.3 \mathrm{~g})$ Zinc (II) complexes). The petri plates were incubated at $37{ }^{\circ} \mathrm{C}$ for 24 hours in incubator during which activity was evidenced by the presence of a zone of inhibition (mm) surrounding the well.

\section{Characterization of Complexes Synthesis}

\section{RESULTS AND DISCUSSION}

5-(benzylideneamino)-1,3,4-thiadiazole-2-thiol Schiff bases compound was used to evaluate biological activity. These complexes were analyzed using Infrared and UV-vis spectra. The FTIR spectrum for Schiff bases, showed appearance of $\mathrm{N}-\mathrm{H}_{\text {str }}$, peak at $(3407) \mathrm{cm}^{-1}, \mathrm{~S}-\mathrm{H}_{\mathrm{str}}$ band at (2594) $\mathrm{cm}^{-1}$. The absorption bands at $(1592) \mathrm{cm}^{-1}$ due to $\mathrm{C}=\mathrm{N}_{\text {str }},(1367) \mathrm{cm}^{-1}$ due to $\mathrm{C}=\mathrm{S}$ and showed the C-S vibrational band at $(944.1) \mathrm{cm}^{-1}$ this property made it easily coordinating with most metals forming clonal complexes with nitrogen and sulfur atoms shown in scheme (3). the complexes showed weak vibrational bands of $\mathrm{N}-\mathrm{H}_{\text {str }}, \mathrm{S}-\mathrm{H}_{\text {str }}$ at same region $(3379.1-3147.6) \mathrm{cm}^{-1}$ respectively because of tautomerism $(\mathrm{S}-\mathrm{H})$ with $(\mathrm{N}-\mathrm{H})$ groups, while appears shifting strong sharp double band for $\mathrm{C}=\mathrm{N}_{\mathrm{str}}$ from $(1477.4) \mathrm{cm}^{-1}$ to $(1398.3) \mathrm{cm}^{-1}$. The absorption bands at $(1271-1245.9) \mathrm{cm}^{-1}$ and at (944.1-696.3) $\mathrm{cm}^{-1}$ due to $\mathrm{C}-\mathrm{S}_{\text {str }}$, this indicated coordination of metals with $\mathrm{C}=\mathrm{N}$ and $\mathrm{S}-\mathrm{H}$ of Schiff bases compound, shown (Table 1).

UV-visible spectrum of Schiff bases compound $(C=N)$ and $(C=S)$ showed intense at $(224 \mathrm{~nm})$ and $(313 \mathrm{~nm})$ which refer to $\pi \rightarrow \pi^{*}$ and $\mathrm{n} \rightarrow \pi^{*}$ electronic transition respectively, however its complexes demonstrates shifting the absorption band at $(307 \mathrm{~nm}),(292 \mathrm{~nm}),(272 \mathrm{~nm}),(320 \mathrm{~nm})$ due to $\mathrm{LM}_{1}, \mathrm{LM}_{2}, \mathrm{LM}_{3}, \mathrm{LM}_{4}$ respectively that refer to electronic transition at $\pi \rightarrow \pi^{*}$ and $\mathrm{n} \rightarrow \pi^{*}$ shown (Table 2).

Table 1: Infrared Spectroscopy (FTIR) wave number $\mathrm{cm}^{-1}$ for Schiff bases and complexes compound

\begin{tabular}{|c|c|c|c|c|c|}
\hline Groups & $\begin{array}{c}\text { Schiff bases } \\
\text { compounds }\end{array}$ & $\mathbf{L M}_{\mathbf{1}}$ & $\mathbf{L M}_{\mathbf{2}}$ & $\mathbf{L M}_{\mathbf{3}}$ & $\mathbf{L M}_{\mathbf{3}}$ \\
\hline${\mathrm{S}-\mathrm{H}_{\text {str }}}$ & 2594 & 3379.1 & 3412.1 & 3147.6 & 3450.4 \\
\hline $\mathrm{N}-\mathrm{H}_{\text {str }}$ & 3407 & 3379.1 & 3412.1 & 3147.6 & 3450.4 \\
\hline $\mathrm{C}=\mathrm{N}_{\text {str }}$ & 1592.1 & 1477.4 & 1413.7 & 1398.3 & 1425.3 \\
\hline $\mathrm{C}=\mathrm{S}_{\text {str }}$ & 1367 & 1271 & 1263 & 1245.9 & 1265.2 \\
\hline${\mathrm{C}-\mathrm{S}_{\text {str }}}$ & 944.1 & 995.2 & 940.3 & 873.7 & 696.3 \\
\hline
\end{tabular}

Table 2: Ultraviolet spectroscopy (UV-VIS) wave length $\lambda \mathbf{n m}$ for Schiff bases and complexes compound

\begin{tabular}{|c|c|}
\hline Compound & wave length $\boldsymbol{\lambda}$ (nm) \\
\hline Schiff bases compound & 313 \\
\hline $\mathrm{LM}_{1}$ & 307 \\
\hline $\mathrm{LM}_{2}$ & 292 \\
\hline
\end{tabular}




\begin{tabular}{|c|c|}
\hline $\mathrm{LM}_{3}$ & 272 \\
\hline $\mathrm{LM}_{4}$ & 320 \\
\hline
\end{tabular}

\section{Bacterial Identification}

The identification of bacteria was performed using VITEK2 compact system, as described in the following image for Alloiococcus otitis :

\begin{tabular}{|c|c|c|c|c|c|c|c|c|c|c|c|c|c|c|c|c|}
\hline \multicolumn{3}{|c|}{ Selected Organism } & & \multicolumn{9}{|c|}{ Blonumber: 000002000000020} & Confidence: & & \multicolumn{2}{|c|}{$\begin{array}{l}\text { Very good } \\
\text { identification }\end{array}$} \\
\hline \multicolumn{4}{|c|}{$\begin{array}{l}\text { SRFF } \\
\text { Onganism }\end{array}$} & & & & & & & & & & & & & \\
\hline \multicolumn{17}{|c|}{ Analysio Organlsms and Tests to Soparate: } \\
\hline \multicolumn{17}{|c|}{ Analysis Messages: } \\
\hline \multicolumn{17}{|c|}{ Contraindicating Typical Biopattern(s) } \\
\hline \multicolumn{17}{|c|}{ Biochemical Details } \\
\hline 2 & AMY & & 4 & PIPLC & $\because 5$ & 5 & QXYL & 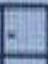 & 8 & $\mathrm{AOH1}$ & - & 9 & BGAL & $E$ & 11 & AGLU \\
\hline 13 & APPA & - & 14 & CDEX & -1 & 15 & Aspa & 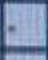 & 16 & BGAR & E & 17 & AMAN & 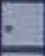 & 19 & PHOS \\
\hline 20 & LeuA & - & 23 & ProA & -2 & 24 & BGURr & - & 25 & AGAL & E & 26 & Byta & + & 27 & BGUR \\
\hline 28 & AlaA & $=$ & 29 & TyrA & $\cdot 3$ & 30 & dSOR & - & 31 & URE & $E$ & 32 & POLYB & 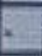 & 37 & dGAL \\
\hline 38 & dRIB & : & 39 & ILATK & .14 & 42 & $\angle A C$ & - & 44 & NAG & E & 45 & dMAL & $E$ & 46 & $B A C l$ \\
\hline 47 & NOVO & F. & 50 & NC6.5 & -5 & 52 & dMAN & 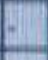 & 53 & ¿MNE & 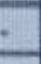 & 54 & MBdo & $=$ & 56 & PUL \\
\hline 57 & dRAF & - & 58 & O129R & .5 & 59 & SAL & : & 60 & SAC & . & 62 & dTRE & + & 63 & $\mathrm{ADH} 2 \mathrm{~s}$ \\
\hline 64 & OPTO & t. & & & & & & & & & & & & & & \\
\hline
\end{tabular}

The confirmation tests of diagnostic bacterial isolates that depends on biochemical and phenotypic properties were described in (Table 3).

Table 3: Routine identification tests and characteristics of gram negative and positive uncommon isolates

\begin{tabular}{|c|c|c|c|c|c|c|c|}
\hline Bacterial species & 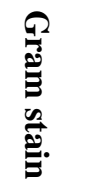 & 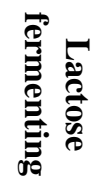 & 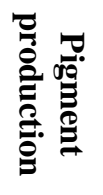 & 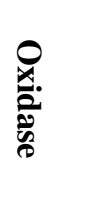 & 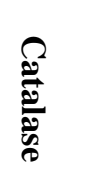 & $\begin{array}{l}\overline{\bar{z}} \\
\bar{o} \\
\frac{0}{\partial}\end{array}$ & 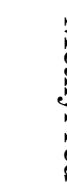 \\
\hline Kocuria kristinae & $\mathrm{G}^{+} \mathrm{ve}$ & + & + & + & - & ND & ND \\
\hline Alloiococcus otitis & $\mathrm{G}^{+}$ve & - & + & - & + & ND & ND \\
\hline Aerococcus urinae & $\mathrm{G}^{+}$ve & - & - & - & - & ND & ND \\
\hline Pseudomonas stutzeri & $\mathrm{G}^{-} \mathrm{ve}$ & - & - & + & & & \\
\hline $\begin{array}{l}\text { Ochrobactrum } \\
\text { anthropi }\end{array}$ & $\mathrm{G}^{-} \mathrm{ve}$ & - & - & + & + & & \\
\hline
\end{tabular}




\begin{tabular}{|l|l|l|l|l|l|l|l|l|l|}
\hline Pantoea agglomerans & $\mathrm{G}^{-} \mathrm{ve}$ & - & + & - & + & - & & + & + \\
\hline
\end{tabular}

$\mathrm{G}^{-}$ve: Gram negatine , $\mathrm{G}^{+}$ve: Gram positive, ND: not done

\section{Susceptibility of Uncommon Bacteria to Antibiotics}

Antibiotic resistance is now generally accepted as a major public health issue. Kocuria kristinae was resistant to 18 (75\%) antibiotics but sensitive to meropenem, doripenem, ciprofloxacin, tetilmycin, Doxicycline and tetracycline as shown in (Table 4). Also Alloiococcus otitis was resistant to 22(91.6\%) antibiotics but it was sensitive for nitrofurantoin and netilmicin. Aerococcus urinae was resistant to 23(95.8\%) antibiotics expect nitrofurantoin. Pseudomonas stutzeri was resistant to $17(70.84 \%)$ antibiotics and it was inhibited by carbapenem and fluoroquinolones in addition to tobramycin, tetilmycin and amikacin that are aminoglycosides which prevent translation of mRNA during binding to the $30 \mathrm{~S}$ ribosomal subunit (Kiser et al., 2011). Ochrobactrum anthropic was resistant to 20 (83.3\%) antibiotics and it was sensitive for carbapenem (meropenem, doripenem) and fluoroquinolones (levofloxacin, ciprofloxacin). Resistance to carbapenems occurs and mediated by mechanisms like the loss of outer membrane proteins and production of $\beta$-lactamase that is capable of hydrolyzing carbapenems. Resistance to all $\beta$-lactams, except imipenem, is mediated through the production of an AmpC $\beta$-lactamase, OCH-1 (membrane bound mannosyltransferase) (Romano et al., 2009). On the other hand the reason for the resistance to the fluoroquinolones antibiotics is that these bacteria have a gene responsible for the resistance as well as mutations that lead to alterations in the DNA gyrase or may be due to mutations leading to the production of efficient efflux systems (Wang et al.,2004), while Pantoea agglomerans was resistant to all the antibiotics except sensitive to tetilmycin. Tetracycline group are bacteriostatic that inhibit the binding of aminoacyl-tRNA to the 30S ribosomal subunit of the bacterial ribosome. Bacteria resistance to tetracycline resistance results from the loss of bacterial outer membrane proteins, which reduces the permeability of the antibiotic into the bacteria (Brooks et al., 2007). All bacterial isolates were $100 \%$ resistant to the cephalosporin antibiotics. The bacterial sensitivity to the beta-lactam group is due to the ability of these antibiotic to bind to the PBPs on the bacterial cell wall, thus inhibiting the manufacture of the bacterial cell wall. The bacterial resistance to these antibiotic is due to the ability to change the target sites of the antibiotic, and the production of the beta lactamase enzymes which break the ring of Beta-lalctam, change in the permeability barrier or weaken the affinity between the antibiotic and target sites PBPs (Talaro, 2010). Results of the present study disagree completely with (Bosley et al., 1995) who demonstrated intermediate levels of resistance to $\beta$-lactams, including expanded spectrum cephalosporins, and were resistant to trimethoprim sulfamethoxazole and erythromycin. Also Humphries and Hindler (2014) conducted no standardized susceptibility test methods or interpretive criteria have been proposed for Aerococcus urinae.

Results of the present study is correlate to the study in Erbil city by Abdullah and Barzani (2016) showed the susceptibility of some gram positive to 13 antibiotics, they found that most of the isolates were highly resistant to amoxicillin/ clavulanic acid with the percentage $81.53 \%$ while, the most effective antibiotics were imipenem with the percentage $96 \%$ for both antibiotics and also showed variable sensitivity to other antibiotics. 
Table 4: resistance of bacterial isolates to antibiotics

\begin{tabular}{|c|c|c|c|c|c|c|c|}
\hline $\begin{array}{c}\text { Bacteria } \\
\text { species } \\
\text { Antibiotic }\end{array}$ & 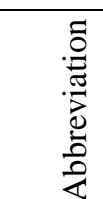 & 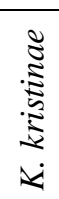 & 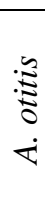 & \begin{tabular}{l}
$\mathscr{\Xi}$ \\
\multirow{\Xi}{\Xi}{} \\
$\dot{+}$
\end{tabular} & 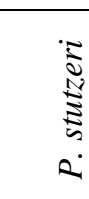 & 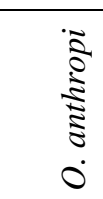 & 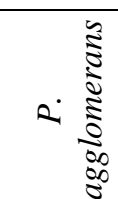 \\
\hline Meropenem & MEM & $S$ & $\mathrm{R}$ & $\mathrm{R}$ & $S$ & S & $\mathrm{R}$ \\
\hline Dorepenm & DOR & $\mathrm{S}$ & $\mathrm{R}$ & $\mathrm{R}$ & $\mathrm{S}$ & $\mathrm{S}$ & $\mathrm{R}$ \\
\hline Azteronam & ATM & $\mathrm{R}$ & $\mathrm{R}$ & $\mathrm{R}$ & $\mathrm{R}$ & $\mathrm{R}$ & $\mathrm{R}$ \\
\hline Amoxiclave & AMC & $\mathrm{R}$ & $\mathrm{R}$ & $\mathrm{R}$ & $\mathrm{R}$ & $\mathrm{R}$ & $\mathrm{R}$ \\
\hline Pipracillin & PRL & $\mathrm{R}$ & $\mathrm{R}$ & $\mathrm{R}$ & $\mathrm{R}$ & $\mathrm{R}$ & $\mathrm{R}$ \\
\hline Penciilin G & PG & $\mathrm{R}$ & $\mathrm{R}$ & $\mathrm{R}$ & $\mathrm{R}$ & $\mathrm{R}$ & $\mathrm{R}$ \\
\hline Cefadroxil & CER & $\mathrm{R}$ & $\mathrm{R}$ & $\mathrm{R}$ & $\mathrm{R}$ & $\mathrm{R}$ & $\mathrm{R}$ \\
\hline Cephalothin & $\mathrm{KF}$ & $\mathrm{R}$ & $\mathrm{R}$ & $\mathrm{R}$ & $\mathrm{R}$ & $\mathrm{R}$ & $\mathrm{R}$ \\
\hline Ampicillin & AMP & $\mathrm{R}$ & $\mathrm{R}$ & $\mathrm{R}$ & $\mathrm{R}$ & $\mathrm{R}$ & $\mathrm{R}$ \\
\hline Cefazolin, & $\mathrm{KZ}$ & $\mathrm{R}$ & $\mathrm{R}$ & $\mathrm{R}$ & $\mathrm{R}$ & $\mathrm{R}$ & $\mathrm{R}$ \\
\hline Cefotacxime & CTX & $\mathrm{R}$ & $\mathrm{R}$ & $\mathrm{R}$ & $\mathrm{R}$ & $\mathrm{R}$ & $\mathrm{R}$ \\
\hline Ceftazidime & CAZ & $\mathrm{R}$ & $\mathrm{R}$ & $\mathrm{R}$ & $\mathrm{R}$ & $\mathrm{R}$ & $\mathrm{R}$ \\
\hline Ceftriaxon & CRO & $\mathrm{R}$ & $\mathrm{R}$ & $\mathrm{R}$ & $\mathrm{R}$ & $\mathrm{R}$ & $\mathrm{R}$ \\
\hline Cefexime & CFM & $\mathrm{R}$ & $\mathrm{R}$ & $\mathrm{R}$ & $\mathrm{R}$ & $\mathrm{R}$ & $\mathrm{R}$ \\
\hline Cefepem, & CFP & $\mathrm{R}$ & $\mathrm{R}$ & $\mathrm{R}$ & $\mathrm{R}$ & $\mathrm{R}$ & $\mathrm{R}$ \\
\hline Ciprofloxacin & CIP & $\mathrm{S}$ & $\mathrm{R}$ & $\mathrm{R}$ & $\mathrm{S}$ & $\mathrm{S}$ & $\mathrm{R}$ \\
\hline Levofloxacin & LEV & $\mathrm{R}$ & $\mathrm{R}$ & $\mathrm{R}$ & $\mathrm{S}$ & $\mathrm{S}$ & $\mathrm{R}$ \\
\hline Amikacin & $\mathrm{AK}$ & $\mathrm{R}$ & $\mathrm{R}$ & $\mathrm{R}$ & $\mathrm{S}$ & $\mathrm{R}$ & $\mathrm{R}$ \\
\hline Tobramycin & TOB & $\mathrm{R}$ & $\mathrm{R}$ & $\mathrm{R}$ & $S$ & $\mathrm{R}$ & $\mathrm{R}$ \\
\hline Netilmicin & NET & $\mathrm{S}$ & $\mathrm{S}$ & $\mathrm{R}$ & $\mathrm{S}$ & $\mathrm{R}$ & $\mathrm{S}$ \\
\hline Doxicycline & DO & $\mathrm{S}$ & $\mathrm{R}$ & $\mathrm{R}$ & $\mathrm{R}$ & $\mathrm{R}$ & $\mathrm{R}$ \\
\hline Tetracycline & TE & $S$ & $\mathrm{R}$ & $\mathrm{R}$ & $\mathrm{R}$ & $\mathrm{R}$ & $\mathrm{R}$ \\
\hline Nitrofuranton & $\mathrm{F}$ & $\mathrm{R}$ & $\mathrm{S}$ & $\mathrm{S}$ & $\mathrm{R}$ & $\mathrm{R}$ & $\mathrm{S}$ \\
\hline Trimethoprime & W & $\mathrm{R}$ & $\mathrm{R}$ & $\mathrm{R}$ & $\mathrm{R}$ & $\mathrm{R}$ & $\mathrm{R}$ \\
\hline
\end{tabular}

\section{Antibacterial Activity of Complexes}

The growing numbers of antimicrobial-resistant pathogens, which are increasingly associated with nosocomial infection, place a significant burden on healthcare systems and have important global economic costs (Bush and Jacoby, 2010). The complexes Cobalt (II) complexes, Ferric (III) complexes, Copper (II) complexes and Zinc (II) complexes were screened in vitro for their ability to inhibit the growth of some uncommon pathogenic bacteria. It can be observed from (Table 5) that the Cobalt (II) complexes exhibit high activity of inhibition at concentration $(0.1 \mathrm{M})$ against the bacterium Kocuria kristinae with clear zone of inhibition about $34 \mathrm{~mm}$. Alloiococcus otitis, Aerococcus urinae, Pseudomonas stutzeri and Ochrobactrum anthropic with 30, 25, 20, $24 \mathrm{~mm}$ respectively. The zone of inhibition represent the activity of this complex on P. agglomerans with less value $16 \mathrm{~mm}$. Ferric (III) complexes exhibit close results with Cobalt (II) complexes with the zone of inhibition (30 mm) for K. kristinae, A. otitis, A. Urinae, O. anthropi and P. agglomerans. 
Whereas $P$ aeruginosa. exhibit less sensitivity about $22 \mathrm{~mm}$ in concentration $0.3 \mathrm{M}$. Copper (II) complexes exhibited a greater activity against all the studied pathogenic bacteria compared with Cobalt (II) complexes and Ferric (III) complexes as showed in (Table 5). The highest antimicrobial activity observed against $A$. urinae with zone of inhibition about $34 \mathrm{~mm}$ at $0.3 \mathrm{M}$ concentration compared with $(30,28,20,30,28)$ for $K$. kristinae, A. otitis, P. stutzeri, O. Anthropi and P. agglomerans respectively at the same concentration. The results of antibacterial activity of Zinc (II) complexes in concentration $0.3 \mathrm{M}$ revealed a broad spectrum of activity against all uncommom pathogens compared with other complexes as showed in (Table 5). The higher value was $40 \mathrm{~mm}$ of Gram positive uncommon bacteria $K$. kristinae, A. otitis and A. urinae, followed by $35,36,30 \mathrm{~mm}$ of $P$. stutzeri, $O$. anthropi and $P$. agglomerans. Fig. (1, 2, 3 and 4) showed the zone of inhibition against some pathogenic uncommon bacteria).

Several studies were investigate the effectiveness of Thiadiazoles and its derivatives on varies pathogenic microbes as a new treatment, so this results was similar to (Rehab and Eiman, 2014) who demonstrated that the [3-dicyclohexyl amino methyl -2- mercaptobenzothiazole] [E] and its derivatives have high activity against E.coli and S.aureus. Also our results are in consistence with (Seelam et al., 2013) who synthesized N-benzylidene- 5-ptolyl-1,3,4-thiadiazole derivatives.

Table 5: Antibacterial activities of complexes

\begin{tabular}{|c|c|c|c|c|c|c|c|c|}
\hline \multirow[t]{2}{*}{ Bacteria } & \multicolumn{8}{|c|}{ Complexes } \\
\hline & con./M & E1 & con./M & E2 & con./M & E3 & con./M & E4 \\
\hline \multirow[t]{3}{*}{ K. kristinae } & 0.03 & 25 & 0.1 & 25 & 0.1 & 20 & 0.1 & 30 \\
\hline & 0.05 & 30 & 0.2 & 28 & 0.2 & 24 & 0.2 & 35 \\
\hline & 0.1 & 34 & 0.3 & 30 & 0.3 & 30 & 0.3 & 40 \\
\hline \multirow[t]{3}{*}{ A. otitis } & 0.03 & 18 & 0.1 & 25 & 0.1 & 22 & 0.1 & 28 \\
\hline & 0.05 & 24 & 0.2 & 28 & 0.2 & 25 & 0.2 & 30 \\
\hline & 0.1 & 30 & 0.3 & 30 & 0.3 & 28 & 0.3 & 40 \\
\hline \multirow[t]{3}{*}{ A. urinae } & 0.03 & 12 & 0.1 & 22 & 0.1 & 15 & 0.1 & 30 \\
\hline & 0.05 & 18 & 0.2 & 28 & 0.2 & 28 & 0.2 & 36 \\
\hline & 0.1 & 25 & 0.3 & 30 & 0.3 & 34 & 0.3 & 40 \\
\hline \multirow[t]{3}{*}{ P. stutzeri } & 0.03 & 10 & 0.1 & 15 & 0.1 & 12 & 0.1 & 22 \\
\hline & 0.05 & 15 & 0.2 & 20 & 0.2 & 15 & 0.2 & 30 \\
\hline & 0.1 & 20 & 0.3 & 22 & 0.3 & 20 & 0.3 & 35 \\
\hline \multirow[t]{3}{*}{ O. anthropi } & 0.03 & 16 & 0.1 & 22 & 0.1 & 12 & 0.1 & 28 \\
\hline & 0.05 & 20 & 0.2 & 25 & 0.2 & 20 & 0.2 & 30 \\
\hline & 0.1 & 24 & 0.3 & 30 & 0.3 & 30 & 0.3 & 36 \\
\hline \multirow[t]{3}{*}{ P. agglomerans } & 0.03 & 8 & 0.1 & 22 & 0.1 & 18 & 0.1 & 22 \\
\hline & 0.05 & 12 & 0.2 & 26 & 0.2 & 24 & 0.2 & 28 \\
\hline & 0.1 & 16 & 0.3 & 30 & 0.3 & 28 & 0.3 & 30 \\
\hline
\end{tabular}

E1: inhibition zone (mm) of (Cobalt (II) complexes)

E2: inhibition zone (mm) of (Ferric (III) complexes)

E3: inhibition zone (mm) of (copper (II) complexes)

E4: inhibition zone ( $\mathrm{mm}$ ) of (Zinc (II) complexes) 


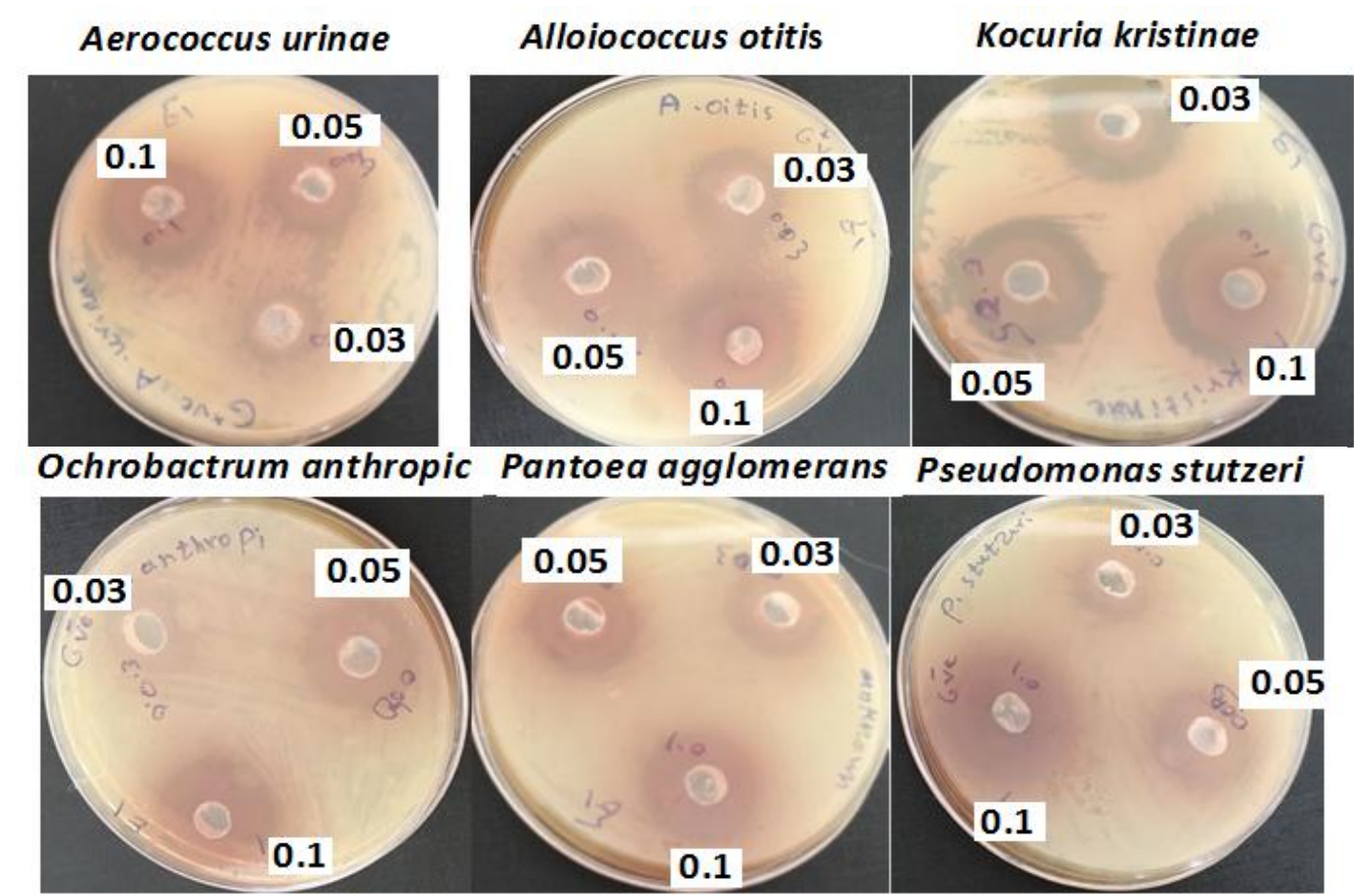

Fig. 1: The activity of Cobalt (II) complexes on some uncommon bacteria
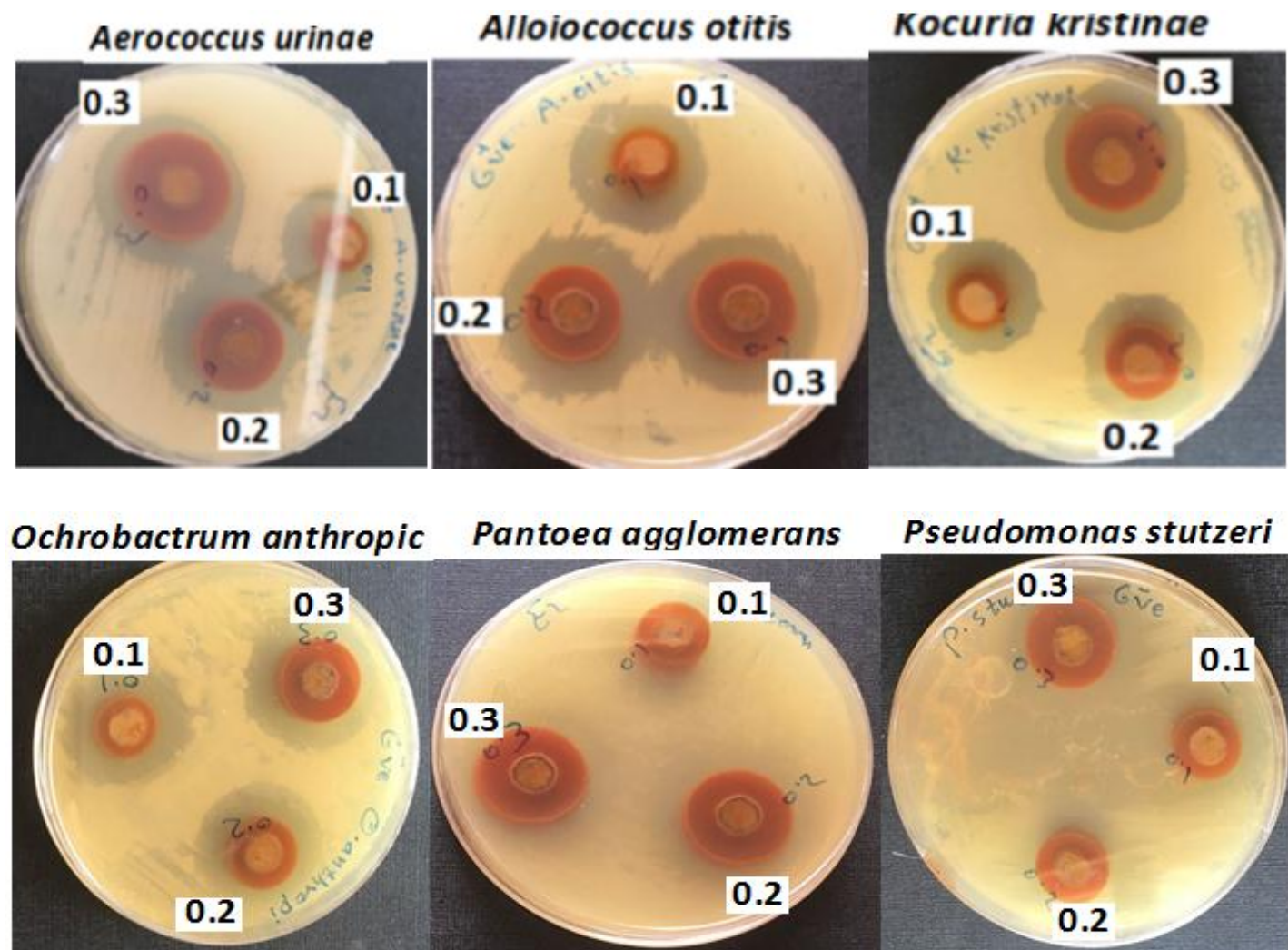

Fig. 2: The activity of Ferric (III) complexes on some uncommon bacteria 

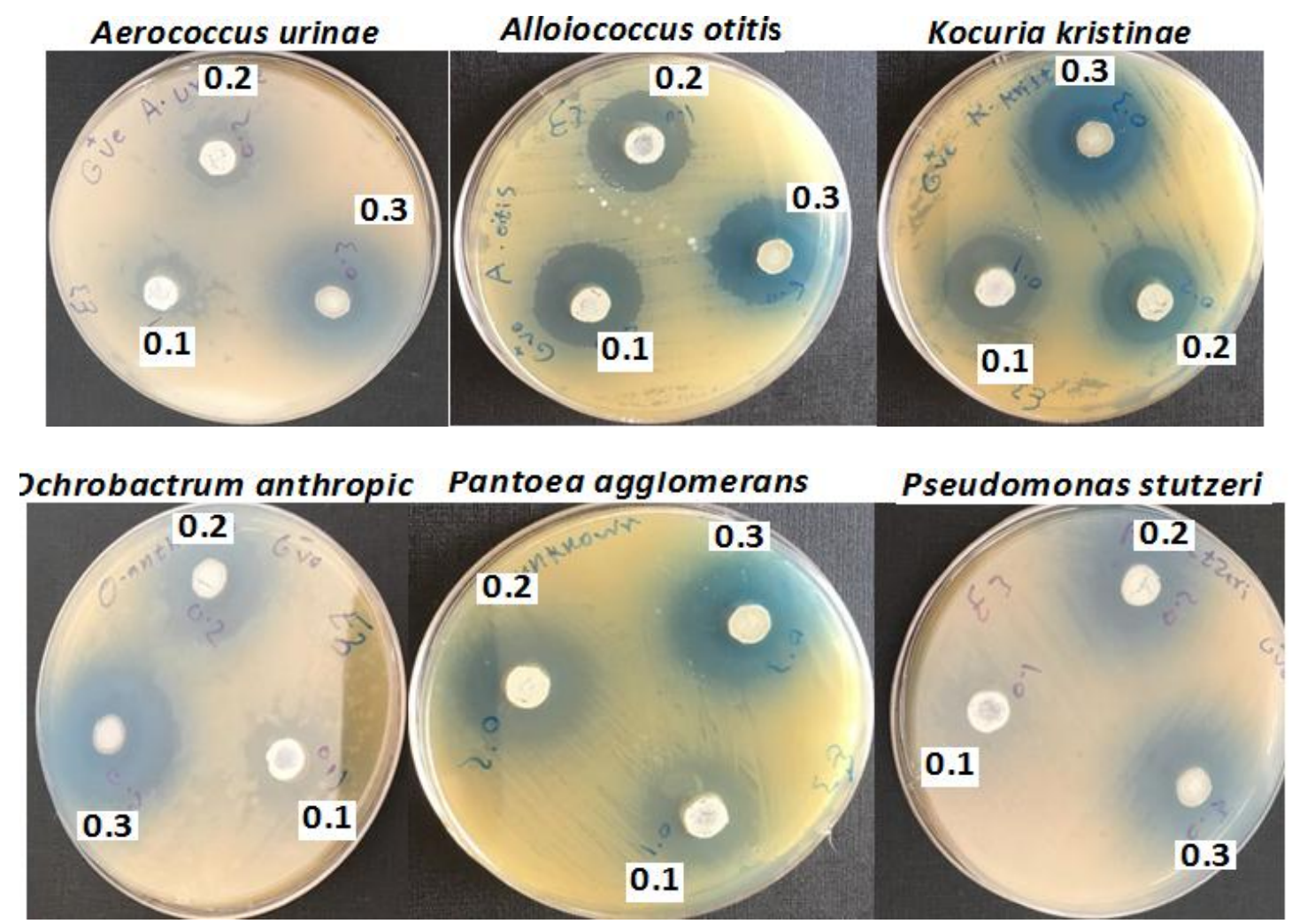

Fig. 3: The activity of Copper (II) complexes on some uncommon bacteria

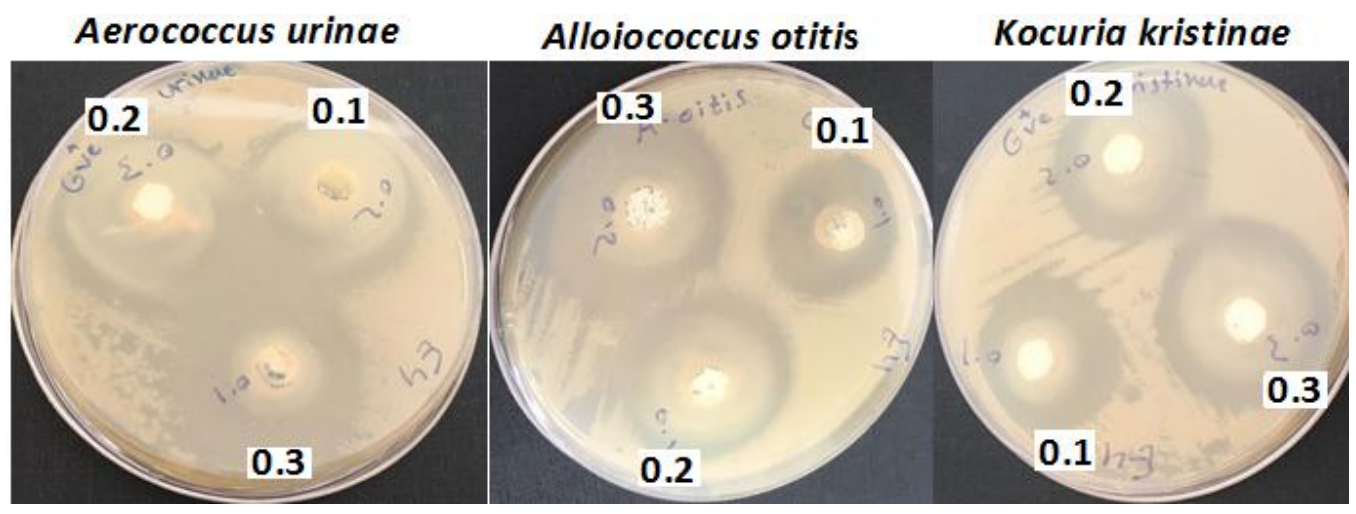

\section{Ochrobactrum anthropic Pantoea agglomerans Pseudomonasstutzeri}

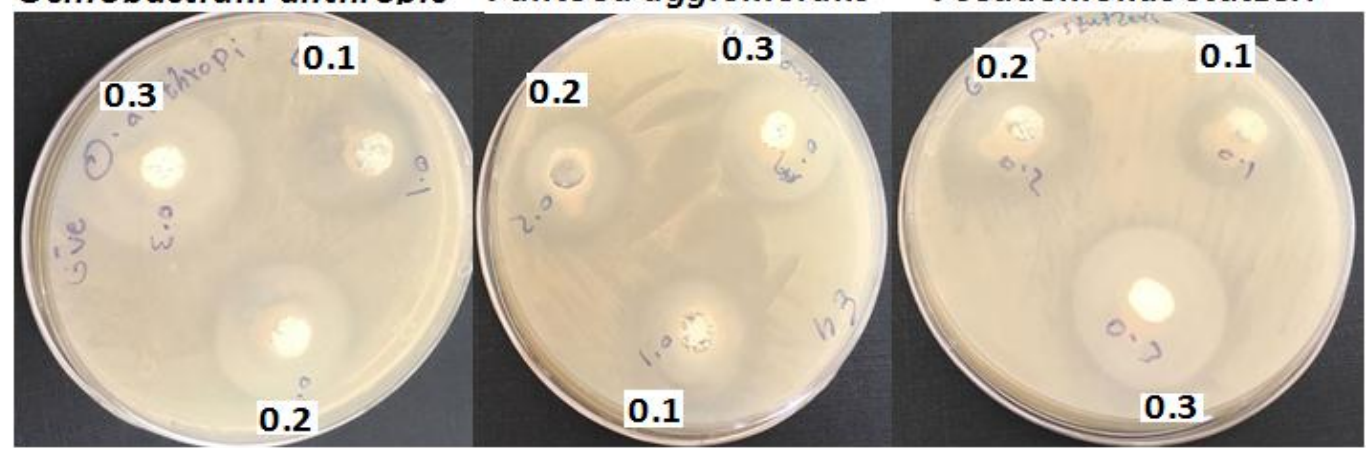

Fig. 4: The activity of Zinc (II) complexes on some uncommon bacteria

\section{CONCLUSION}

Zinc (II) complexes have the greater activity against uncommon pathogenic bacteria compared with other complexes and traditional antibiotic, followed by Copper (II) complexes which exhibit a 
higher effectiveness toward Gram positive compared with Gram negative bacteria. Cobalt (II) complexes revealed moderate activity when compared with other complexes (Zinc (II) complexes and Copper (II) complexes) Ferric (III) complexes was exhibit less activity compared with other complexes, but when compared with other antibiotic this complex showed a great activity toward all the uncommon pathogenic bacteria.

\section{REFERENCES}

Abdul-Jabar, K.; Fouad, M.; Aoras, A. (2014). Synthesis, characterization and anti-bacterial activities of some new $\beta$-Lactam thiadiazole derivatives. J. Al-Mustansiriyah Sci., 25, 103-112.

Abdullah, Z.H.A.; Barzani, K.H. (2016). Bacteriological and molecular study of gram positive bacteria isolated from thalassemic patients in Erbil city. ZJPAS, 28(5), 163-181.

Hooton, T.M. (2000). Pathogenesis of urinary tract infections; an update. J. Antimicrob Chemother. 46, 1-7. Female General Practice Patients. Fam. Pract., 22, 71-77.

Aguirre, M.; Collins, M.D. (1992). Phylogenetic analysis of Alloiococcus otitis gen. nov., sp. nov., an organism from human middle ear fluid. Int. J. Syst. Bacteriol. 42(1), 79-83.

Ana, A.; Panagiotis, M.; Zoumpoulakis, M. (2010). Sulfonamide-1,2,4-thiadiazole derivatives as antifungal and antibacterial agents: synthesis, biological evaluation, lipophilicity and conformational studies. J. Chem. and Pharmaceutical Bulletin. 58, 160-167.

Bosley, G.S.; Whitney, A.M.; Pruckler, J.M.; Moss, C.W.; Daneshvar, M.; Sih, T.; Talkington, D.F. (1995). Characterization of ear fluid isolates of Alloiococcus otitidis from patients with recurrent otitis media. J. Clin. Microbiol. 33(11), 2876-2880.

Brooks, G.F.; Butel, J.S.; Morse, S.A. (2007). "Jawetz, Melenik and Adelberg's Medical Microbiology". 23 ${ }^{\text {rd }}$ ed. The McGraw- Hill companies. Appleton and Lange. New York.

Bush, K.; Jacoby, G. (2010). Updated functional classification of $\beta$-lactamases, Antimicrobial Agents and Chemotherapy, 54(3), 969-976.

Chain, P.S.; Lang, D.M.; Comerci, D.J.; Malfatti, S.A.; Vergez, L.M.; Shin, M.; Ugalde, R.A.; Garcia, E.; Tolmasky, M.E. (2011). Genome of Ochrobactrum anthropi ATCC 49188T, a versatile opportunistic pathogen and symbiont of several eukaryotic hosts. J. Bacteriol. 193(16), 4274-4275.

Cheung, C.Y.; Cheng, N.H.; Chau, K.F.; Li, C.S. (2011). An unusual organism for CAPD-related peritonitis: Kocuria kristinae. Perit. Dial. Int., 31(1), 107-108.

CLSI. (2007). Performance standards for antimicrobial susceptibility testing. Seventeenth Informational Supplement, 26, 3.

De Baere, T.; Verhelst, R.; Labit, C.; Verschraegen, G.; Wauters, G.; Claeys, G.; Vaneechoutte, M. (2004). Bacteremic infection with Pantoea ananatis. J. Clin. Microbiol., 42(9), 43934395.

Egorove, N. (1985). Antibiotics a scientific approach Fermentation, Purification and Biological Activities". J. American-Eurasian Agric. Environ, 5(3), 368-377.

Georgeta, S.; Stela, C.; Eva, E.; Anamaria, S. (2010). Synthesis of some 2-r-5-formil-1,3,4thiadiazole derivatives by sommelet reaction. J. Farmacia., 58(6), 811-822.

Grimaldi, D.; Podglajen, I.; Aubert, A.; Buu-Hoï, A.; Diebold, B.; Mainardi, J.L. (2009). Case of indolent endocarditis due to Pseudomonas stutzeri with genetic evidence of relapse after 4 years. J. Clin. Microbiol., 47(2), 503-504.

Humphries, R.M.; Hindler; J.A. (2014). In vitro antimicrobial susceptibility of Aerococcus urinae. J. Clin. Microbiol., 52(6), 2177-2180.

Ispir, E.; Kurtoglu, M.; Purtas, F. (2005). Synthesis and antimicrobial activity of new Schiff bases having the $-\mathrm{SiOR}$ group $(\mathrm{R}=\mathrm{CH} 3$ or $\mathrm{CH} 2 \mathrm{CH} 3)$, and their transition metal complexes. $J$. Trans. Met. Chem., 30, 1042-1047. 
Kiser, K.M.; Payne, W.C.; Taff, T.A. (2011). "Clinical Laboratory Microbiology a Practical Approach". Pearson Education, Inc., New Jersey.

Kloos, W.E.; Tornabene, T.G.; Schleifer, K.H. (1974). Isolation and characterization of micrococci from human skin, including two new species: Micrococcus lylae and Micrococcus kristinae. Int. J. Syst. Bacteriol., 24(1),79-101.

Kadhim, K.G.; Shaimaa, R.B.; Ekbal, R.H. (2014). Antimicrobial activity of some 1,3,4Thiadaiazole metal complexes. J. Al-Nahrain University. 17(2), 1-8.

Leskinen, K.; Hendolin, P.; Virolainen-Julkunen, A.; Ylikoski, J.; Jero, J. (2002). The clinical role of Alloiococcus otitidis in otitis media with effusion. Int. J. Pediatr. Otorhinolyngol. 66(1), 41-48.

Laura, S.; Barbuceanu, G.; Ioana, G. (2010). Synthesis and antimicrobial evaluation of some fused heterocyclic $[1,2,4]$ triazolo [3,4-b][ 1,3,4]thiadiazole derivatives. J. Med. Chem. 45, 6139 $-6146$.

Mahon, C.; Manuselis, G.; Lehman, D. (2015). "Textbook of Diagnostic Microbiology". Elsevier $5^{\text {rd }}$ ed. USA: Saunders Company, 868 p.

Nadjar, D.; Labia, R.; Cerceau, C.; Bizet, C.; Philippon, A.; Arlet, G. (2001). Molecular characterization of chromosomal class $\mathrm{C} \beta$-lactamase and its regulatory gene in Ochrobactrum anthropi. Antimicrob Agents Chemother. 45(8), 2324-2330.

Romano, S.; Aujoulat, F.; Jumas-Bilak, E.; Masnou, A.; Jeannot, J.L.; Falsen, E.; Marchandin, H.; Teyssier, C. (2009). Multilocus sequence typing supports the hypothesis that Ochrobactrum anthropi displays a human-associated subpopulation. BMC Microbiol 9, 267-285.

Rehab, A.; Eiman, S. (2014). Synthesis, characterization and biological activities of mixed ligand complexes of mannich base derived from 2-mercaptobenzothiazole. J. Al-Nahrain University. 17(2), 73-84.

Salih, N.A. (2005). Synthesis of new heterocyclic compounds derived from 2-Amino-5-Mercapto1,3,4-Thiadiazole. PhD. Thesis, College of Science, AL-Nahrain University.

Seelam, N.; Shrivastava, S.; Prasanthi, S. (2013). Synthesis and antimicrobial activity of some novel fused heterocyclic moieties. J. Org. Commun., 6(2), 78-85.

Skov, R.L.; Klarlund, M.; Thorsen, S. (1995). Fatal endocarditis due to Aerococcus urinae. Diagn Microbiol. Infect. Dis., 21(4), 219-221.

Singh, K.; Raparia, S.; Surain, P. (2015). Co(II), Ni(II), Cu(II) and Zn (II) Complexes of 4-(4cyanobenzylideneamino)-3-mercapto-5-oxo-1,2,4-triazine: synthesis, characterization and biological studies. J. Medicinal Chemistry Research., 24(24), 2336-2346.

Talaro, K. (2010). "Foundation in Microbiology Basic Principles". McGraw Hill, ISBN 0-07295077-3.

Vandepitte, J.; Verhaegen, J.; Engbaek, K.; Rohner, P.; Piot, P.; Heuck, C.C. (2003). "Basic Laboratory Procedures in Clinical Bacteriology". WHO. Geneva.

Vasiliy, A.; Valeriy, O.; Lidia, N.; Kristina, A.; Tetyana, V.; Mikhail, S. (2017). Switchable Rearrangements in 1,2,3-Thiadiazole and 1,2,3-Triazole Series. Book of Abstracts International Soc. Heterocyclic Chem., (94).

Wang, X.; Preston, J.F.; Romeo, T. (2004). The pga ABCD locus of Escherichia coli promotes the synthesis of a polysaccharide adhesin required for biofilm formation. J. Bacteriol. 186, $2724-2734$.

Yasser, M.; Hassan, M.; Dildar, A.; Masoom, Y. (2010). Antileishmanial, antimicrobial and antifungal activities of some new aryl azomethines. J. Molecules., 15(2), 660-671.

Zafenello, F.; Malerba, G.; Cataldi, L.; Antoniazzi, F.; Franchini, M.; Monti, E.; Fanos, V. (2010). Genetic risk for recurrent urinary tract infections in humans. J. Biomed. Biotechnol. doi: $10.1155 / 2010 / 321082$. 